\title{
SOVEREIGN CREDIT RISK and CREDIT DEFAULT SWAP SPREAD REFLECTIONS
}

\author{
Neslihan TURGUTTOPBAŞ ${ }^{1}$
}

\begin{abstract}
The already experienced turbulence in the global financial system has focused the attentions of market participants to especially sovereign risk; its major determinants, systematic nature as well as its contagion potential. In this study, the direction of the analysis of the sovereign risk is within the framework of the credit default swap (cds) transactions. The sovereign risk can also be elaborated by using the bond spreads of the sovereign but the latter is also driven by factors other than the sovereign risk such as the interest rate movements, supply conditions, and liquidity.

The already available economical and financial data provides invaluable opportunity to analyze the sovereign risk anticipation of the financial markets as it incorporates the valuation of cds in real crisis times of 2008 and 2009 and 2011-first half of 2012 as well as the before and after economic and financial data of the selected countries namely Brazil, Turkey, Russia, Korea, Greece and Spain.

The relationship between the global financial variables and cds spreads reveals the fact that the risk appetite in the global financial market affects the credit risk perception and consequently cds spreads regardless of the employed indicator of the risk appetite. Specifically, it is also determined that domestic economic situation has significant effects on cds spreads (excluding Greece who experienced considerable turmoil in its economical and financial position), the local variables explain more than 75 percent of the cds spread level and this ratio increases to more than 80 percent when four emerging market countries are referred.
\end{abstract}

Keywords: credit default swaps, sovereign risk, global financial indicators, risk appetite, financial crisis.

JEL classifications: F34, G12, G15

\section{INTRODUCTION}

The nearness of Greece to sovereign default situation which was resulted with the biggest sovereign debt restructuring in the amount of approximately $€ 100$ billion out of the total debt of $€ 350$ billion of the country, triggered the relevant credit default swap transactions under the

\footnotetext{
${ }^{1}$ Atılım University, Faculty of Business Administration, Turkey. E-mail: ntopbas@atilim.edu.tr
} 
restructuring definition of the credit event. This had been constituted an important test of the financial system to the payment on sovereign bonds as referenced in credit default swaps (cds). In fact, this restructuring had been the breaking point of the long lasting Euro zone sovereign debt crisis since 2008, and considered to be the beginning point of another era of financial turmoil which will probably end up with new sovereign default cases.

This experience was an impressive illustration of the usefulness of cds as an insurance against default risk. A cds is a credit derivative contract providing protection against the default risk (credit event) for a given reference entity (sovereign or corporate). The cds may cover a bond issued by the reference entity or the reference entity itself directly (in which case the contract will be unwound through a cash settlement only). Generally, the buyer of the cds has already exposed to the risk of the reference entity by lending it in the form of loans or bonds and, by the use of the cds, she acquires the right to sell the specific bond which she already owns (reference bond issued by the reference entity) at par value if a credit event occurs in exchange of the payments to the seller in the agreed amounts at regular intervals until the cds expires or a credit event occurs. In the latter case, the buyer makes a final payment and the swap is unwound either by delivery of the underlying asset or in cash.

Within this framework, the Depository Trust and Clearing Corporation (DTCC) who provides post-trade processing services for over the counter (OTC) credit derivative trades announced that it completed the restructuring event for the Hellenic Republic (Greece sovereign entity) and a total of US\$2.89 billion in net funds were transferred from net sellers of protection to net buyers in March 2012. The amount of the net funds to be transferred was calculated on the basis of the auction for Greece sovereign bonds which was conducted in accordance with the International Swaps and Derivatives Association (ISDA) protocols ${ }^{2}$ This experience revealed the importance of the legal specification of the "credit events" on the time of the initiation of the cds transaction whether the reference entity is sovereign or corporate.

The already experienced turbulence in the global financial system focused the attentions of the market participants to especially sovereign risk; its major determinants, systematic nature as well as its contagion potential. In this study, the direction of the analysis of the sovereign risk is within the framework of the credit default swap transactions. The sovereign risk can also be elaborated by using the bond spreads of the sovereign but the latter is also driven by

\footnotetext{
${ }^{2} \mathrm{http} / / /$ www.dtcc.com/news/press/releases/2012/dtcc_successfully_completes_greek_cds.php
} 
factors other than the sovereign risk such as the interest rate movements, supply conditions, liquidity etc.

In the first section of this study, the cds will be elaborated especially in terms of the definition of the credit event under the legal documentation. The aim is to underline that not only default, but also restructuring of the debts can result with a cds to be unwounded. The Second section of this Study will begin with a literature review in order to figure out several different approaches to analyze the sovereign credit risk concept. In the next section, the data and the methodology employed to analyze the sovereign risk within the framework of cds transactions and the findings will be revealed.

In the analysis, the multivariate approach of Longstaff, Pan, Pedersen and Singleton (2011) has been employed. In their study, Longstaff et al. (2011) used the country specific macro economical factors such as domestic stock market return, foreign exchange rate against US \$ and foreign reserves of the sovereign and also global financial factors that may indicate the risk appetite such as US Stock Market Returns, US Treasury yields, corporate yield index etc. The main contribution of this study will be covering the data of the whole crisis time of 2008 and 2009 and especially Greece experience in the late 2011 and beginning 2012 although the sample countries is relatively limited.

The already available economical and financial data provides invaluable opportunity to analyze the sovereign risk anticipation of the markets as it incorporates the valuation of cds in real crisis times of 2008 and 2009 and 2011-first half of 2012 of the selected countries namely Brazil, Turkey, Russia, Korea, Greece and Spain. When selecting the countries firstly the countries which have been in trouble in terms of sovereign riskiness such as Greece and Spain were preferred (although they have been considered as developed countries so far), then geographical diversification of the emerging market countries was considered in order to point out the possible region specific developments (if exists).

\section{LITERATURE REVIEW}

As the financial reports of a company reveals the financial position of a corporation, the macro economical factors show the debt payment capacity of the sovereign as well as the vulnerability of this capacity to the external shocks. There exists no agreement on the determinants of sovereign default risk, as reflected in sovereign credit spreads. While some of the analysis shows that the government's ability to service its debt depends on the underlying 
macroeconomic fundamentals and, therefore, is country-specific, some others revealed strong commonality in the movement of cds spreads regardless of the country specifics.

Most of the early studies had taken into account the individual macroeconomic variable(s) as independent variable and test the relationship between those macro-economic variable(s) and cds spreads such as:

- Low Current Account Balance to GDP ratio signals a decrease in the default probabilities of a country and reduces the cds spreads (Georgievska et al. 2008, p.1037)

- High Import to GDP ratio should lead to higher cds spreads as foreign exchange outflow increases (Georgievska et al., 2008)

- High Debt to Export ratio increases cds spreads (Catao \& Sutton, 2002)

- High Reserves to Debt ratio should have a negative relationship with the sovereign cds spread (Catao \& Sutton, 2002)

- High debt to GDP ratio is positively related with cds spreads (Mellios \& Blanc, 2006)

- High inflation rate should increase the credit risk attached to a nation (Mellios \& Blanc, 2006)

- Economical growth decrease the credit risk associated to that country and thus its cds spread (Baek et al., 2005)

- A devaluation of the exchange rate of a country should increase cds spreads as it conveys a doubtful credit position (Baek et al., 2005)

- High Household Debt to GDP ratio of an economy increases the credit risk attached which should lead to higher cds spreads (Reinhart \& Rogoff, 2008)

- The Risk-free rate should be negatively related to cds spreads (Fontana \& Scheicher, 2010)

- Spreads on emerging market instruments have strong and well-defined relationships to their credit rating, maturity, and currency denomination. (Kamin \& Kleist, 1999)

- Sovereign ratings effectively summarize and supplement the information contained in macroeconomic indicators and are therefore strongly correlated with marketdetermined credit spreads (Cantor \& Packer, 1996). 
As cds was originated as an insurance against credit risk, the theoretical findings that particular country specific macro-economical variables determine cds spreads are not surprising. Nevertheless, the observed degree of co-movement of the individual country cds spreads pave the way for researchers to identify the common factor(s) driving sovereign credit risk and to study the common variation in global sovereign cds spreads. The findings supporting the commonalities in credit spreads are summarized below:

- Spreads on sovereign bonds today co-move to a greater extent than they did historically as they are driven more by global events than country specific fundamentals (Mauro, Sussman, \& Yafeh, 2002).

- The sources of credit risk for the emerging markets can be split into three elements: The first element, which is the least relevant, is the result of shocks through countryspecific fundamentals. The second element is the result of global variables, such as US stock market returns and the slope of the US Treasury bond curve and the third and most important, element is the contribution of regional factors, such as a systematic component of the four stock markets, a systematic volatility component and investor sentiment (Weigel \& Gemmill, 2006).

- Since the structural models of sovereign credit risk focus on country-specific factors in explaining the credit spread of sovereigns, they fail to capture aggregate market effects which are important determinants of sovereign credit spreads (Westphalen, 2001).

- A single common factor drives the common portion of variation in sovereign bond spreads for a sample of 15 emerging market countries (McGuire \& Schrijvers, 2003).

- Sizeable common factor in the changes of emerging market spreads is related to international developments. (Garcia-Herrero \& Ortiz, 2007).

- Liquidity, solvency and economic stability variables significantly affect the market premium of country risk as reflected in the cds spreads (Baek, Bandopadhyaya, \& Du, 2005).

- The credit spreads for Mexico, Turkey and Korea share a strong common relation to US stock market volatility as measured by the VIX index ( Pan \& Singleton, 2008).

- The distance-to-default is largely driven by systematic global and regional factors, so investors should treat the credit risk of these emerging markets as nondiversifiable (Weigel \& Gemmill, 2006). 
The research of Longstaff et al. (2011) stipulates that sovereign credit risk is driven much more by global financial market variables and global risk premia than by local economic forces. This dependence on common global factors such as U.S. stock market returns and high-yield spread changes induces significant correlation into the credit spreads of a broad cross-section of sovereign nations. After inclusion of the data of crisis time of 2008 and 2009, they went one step further and determined that both the risk-premium and default-risk components of cds spreads are strongly related to global macroeconomic factors.

Another update research on systemic sovereign credit risk as reflected in the cds spreads are done through comparing the credit risk components of the US and Europe member countries and resulted with interesting findings. (Ang \& Longstaff, 2011) Using a multifactor affine credit model, the sovereign credit risk was decomposed into a systemic component and a sovereign-specific component and it is found that the systemic risk represents a much smaller fraction of total credit risk for US states than is the case for members of the EMU although the reverse was expected.

The commonality in sovereign cds spreads was also elaborated on a consumption based framework and the role of US consumption forecasts and volatility in explaining sovereign cds was investigated (Augustin \& Tedongap, 2011). The findings suggest that sovereign credit risk is priced globally rather than locally, consistent with previous literature.

\section{THE DATA}

The data used in this study is monthly US Dollar denominated cds spreads of the selected countries, namely Turkey, Brazil, Russia, Korea, Greece and Spain with 5 year maturity. 5 year is selected as the relevant maturity in order to better address the reflections of the changes in sovereign default risk to cds premia as 5 years is accepted as the most representative maturity by the market players with regards to its liquidity.

The sample period is from May 2005 to June 2012, this period is selected because of the availability of the data not only of cds spreads but also other country specific and global macroeconomic and financial factors. All of the data is gathered from Datastream. All cds spreads are quoted in basis point (bps) and Table I provide descriptive statistics for credit default swap spreads. 
Table I

Descriptive Statistics for Credit Default Swap Spreads

\begin{tabular}{lrrrrrr}
\hline & Mean & $\begin{array}{c}\text { Standard } \\
\text { Deviation }\end{array}$ & Minimum & Median & Maximum & N \\
\hline Russia & 184,04 & 182,54 & 43 & 137,16 & $1.001,01$ & 86 \\
Brazil & 162,33 & 85,99 & 62,7 & 127,56 & 446,40 & 86 \\
Turkey & 227,07 & 93,88 & 132 & 195,85 & 605,82 & 86 \\
Korea & 102,20 & 94,21 & 14,5 & 93,32 & 450 & 86 \\
Greece & $1.500,586$ & $3.611,67$ & 4,7 & 104,5 & $14.904,36$ & 86 \\
Spain & 103,72 & 117,73 & 1,05 & 61,08 & 449,51 & 86 \\
\hline
\end{tabular}

Table I clearly reveals the situation of cds spreads when default probability increases, as in Greece. The min and max values of cds spreads of Greece diverge considerably while the standard deviation shows great variance. The second highest vulnerable country seems as Russia as reflected in standard deviation, followed by Spain. The most stable cds spread movements belongs to Korea that was prepared to deal with new crisis after 1997-1998 crisis in terms of foreign reserves, improved financial structures of firms and banks, relatively mild house price hikes, and the sound government budget, as well as the foreign exchange policy that honored market forces, the monetary policy that stabilizes domestic economy, and the fiscal policy that was carried out on time (Cho, 2010).

\section{CORRELATIONS AND PRINCIPAL COMPONENT ANALYSIS}

There exist many different views and definitions about the credit risk but it is widely accepted that credit risk consist of two components: the default risk and the spread risk. The default risk is relevant with the non-compliance of the borrower to the legal, financial and operational obligations covered and so, more related with the documentation-related aspect of a transaction creating exposure. The other component is the spread risk and it is relevant with the market value of the contract when the credit quality of the borrower changes. Reflecting this definition of the credit risk to the definition of cds spreads, the decomposition generally clarifies the possible risk factors that may have affect. The magnitude of the default risk component is determined by the factors affecting the probability of the default of the specific entity, sovereign in our analysis, or from a different terminology the arrival rate of default which is highly country-specific. On the other hand, the second component, spread risk is clearly relevant with the market conditions affecting all other transactions such as liquidity in the markets, risk appetite etc. In this framework, the market related component of credit risk is applicable to all cds transactions especially the sovereign cds where sovereigns are from the 
same market segment such as emerging markets so co-movement in the cds spreads of the sovereigns must not be surprising.

Table II

Correlation Matrix of Monthly Changes in Sovereign Credit Default Swap Spreads of the Selected Countries

\begin{tabular}{lcccccc}
\hline & Russia & Brazil & Turkey & Korea & Greece & Spain \\
\hline Russia & 1,0000 & & & & & \\
Brazil & 0,8531 & 1,0000 & & & & \\
Turkey & 0,8254 & 0,8106 & 1,0000 & & & \\
Korea & 0,7846 & 0,6917 & 0,7750 & 1,0000 & & \\
Greece & 0,3639 & 0,3026 & 0,3044 & 0,3801 & 1,0000 & \\
Spain & 0,3040 & 0,2844 & 0,2734 & 0,3294 & 0,3554 & 1,0000
\end{tabular}

It is accepted that the financial market conditions do affect the cds spreads of the sovereigns and this, probably, creates some degree of commonality which can be measured by the correlation between the individual sovereign cds spreads. The commonality is originated from some principal factors which can be measured by principal component analysis. The proposed co-movement of the cds spreads reveals itself on the correlations for the countries and Table II shows the pair-wise correlations of the cds spread changes of the selected countries. It is seen that Greece and Spain considerably diverged from other four countries whereas the other four countries have very high correlations between themselves. Table III indicates support to the idea that in crisis time, the co-movement between the individual country cds spread changes increases. September 2008 is defined as the beginning of the crisis time and the pair wise correlations are calculated by using the data before and after that period. For all of the pair of sovereigns, the correlation increased. The highest increase is realized in the correlations of the Spain with other countries, reflecting the co-movement further.

Table III

Correlation Matrix of Monthly Changes in Sovereign Credit Default Swap Spreads of the Selected Countries Before and After Crisis

\begin{tabular}{l|c|c|c|c|c|c|c|c|c|c|}
\hline & \multicolumn{2}{c}{ Brazil } & \multicolumn{2}{c}{ Turkey } & \multicolumn{2}{c}{ Korea } & \multicolumn{2}{c}{ Greece } & \multicolumn{2}{c}{ Spain } \\
\hline & $\begin{array}{c}\text { before } \\
\text { crisis }\end{array}$ & $\begin{array}{c}\text { after } \\
\text { crisis }\end{array}$ & $\begin{array}{c}\text { before } \\
\text { crisis }\end{array}$ & $\begin{array}{c}\text { after } \\
\text { crisis }\end{array}$ & $\begin{array}{c}\text { before } \\
\text { crisis }\end{array}$ & $\begin{array}{c}\text { after } \\
\text { crisis }\end{array}$ & $\begin{array}{c}\text { before } \\
\text { crisis }\end{array}$ & $\begin{array}{c}\text { after } \\
\text { crisis }\end{array}$ & $\begin{array}{c}\text { before } \\
\text { crisis }\end{array}$ & $\begin{array}{c}\text { after } \\
\text { crisis }\end{array}$ \\
\hline $\begin{array}{l}\text { Russia } \\
\text { Brazil }\end{array}$ & 0,8148 & 0,8723 & 0,6498 & 0,8217 & 0,7073 & 0,8817 & 0,3428 & 0,3821 & 0,2091 & 0,5932 \\
$\begin{array}{l}\text { Turkey } \\
\text { Korea }\end{array}$ & & & 0,8125 & 0,8437 & 0,6928 & 0,8740 & 0,4461 & 0,4297 & 0,2971 & 0,6834 \\
Greece & & & & & 0,5824 & 0,8694 & 0,2944 & 0,3000 & 0,1534 & 0,5403 \\
\hline
\end{tabular}


In order to explain the co-movements in the cds spread of the selected countries into a smaller number of common factors, principal component analysis was performed. Table IV stipulates the principal component analysis of the correlation matrix of cds spread changes as given in Table III. The results indicate that there is significant amount of commonality in the variation of cds spreads. The first principal component captures nearly 62 percent of the variation, whereas the first three components capture nearly 90 percent of the correlation matrix. This finding is parallel to the determinations of Longstaff et al. (2011) although they used a different base period (October 2010- January 2010) and a different sovereign set of 26 countries.

Table IV

Principal Component Analysis Results of the Correlation

Matrix of Monthly cds spread changes

\begin{tabular}{lrr}
\hline $\begin{array}{c}\text { Principal } \\
\text { Component }\end{array}$ & $\begin{array}{c}\text { Percent } \\
\text { Explained }\end{array}$ & Total \\
\hline First & 0,6192 & 0,6192 \\
Second & 0,1707 & 0,7899 \\
Third & 0,1074 & 0,8972 \\
Fourth & 0,0515 & 0,9788 \\
Fifth & 0,0212 & 1,0000 \\
\hline
\end{tabular}

\section{REGRESSION ANALYSIS}

The empirical studies focusing on sovereign risk as reflected in the cds spreads have generally adopted two different approaches, one of which is based on comparing the actual credit spreads with the selected structural model and the other has been regressing the changes in the credit spreads with the change rate of the selected variables. In this study, in order to capture the relationships between the cds spreads and the country-specific and the global financial and economical factors, regression analysis has been performed; the dependent variable is set as the change in cds spreads. The independent variables are determined as the change in the factors summarized below fewer than two main headings, the country-specific variables and the global financial variables.

\section{V.I Country-specific Variables}

The country specific economical variables have been selected by referring their affects to possible payment failure of the sovereign. All the data mentioned below are gathered from Datastream which is a product of Thompson Reuters, unless otherwise stated in the definition of the variable. It is also noteworthy to mention that all of the country-specific factors 
mentioned are also included in the sovereign rating methodology of the major rating agencies as Standard \&Poors and Moody's.

- Cds Spreads: The spreads of US Dollar denominated sovereign cds transactions with 5 years maturity of each country are used.

- Foreign Exchange Rate: The monthly local foreign currency rates per U.S. Dollar against domestic currencies are used. There exist floating exchange rate regimes in all of the selected countries, consequently the foreign exchange rate acts as a barometer against the possible fluctuations in of the countries capability of paying external indebtedness except Spain and Greece having Euro as the domestic currency.

- Foreign Currency Reserves: The U.S.Dollar equivalent of the foreign currency reserves is used. From the lenders side, the higher the amount of such reserves, the more comfortable they feel as in tough times the sovereign will be able to pay its debts without needing further financing.

- Local Stock Market Returns: The monthly changes in the local market indexes are taken as the measure of the local market return. All the countries involved have wellfunctioning local equity markets and those markets reflect not only domestic real economical balances but also the global risk appetite through foreign portfolio investments.

The factors explained above were the ones also employed by Longstaff et al. (2011) who determined that the country-specific factors comes behind the global market factors in determining the sovereign riskiness and cds spreads. In order to better address the sovereign default risk as perceived by the market participants two more country-specific factors have been added to the model:

- External Debt: The U.S.Dollar equivalent of the total external indebtedness of each sovereign is used. From the lenders side the higher the external debt of a country, the more vulnerable it would be to fluctuations in the international funding environment.

- Current Account Balance as a percentage of Gross Domestic Product: This ratio represents all the economic activities of the nation affecting the foreign exchange flows, it includes net foreign trade and also capital flows. This variable is added to the original model referring to the study of Hilsher and Nosbusch (2010) who worked on the effect of particularly the export performance of the countries to its debt paying capacity. 


\section{V.II Global Financial Variables}

Many of the earlier research have ended up with the determination that the cds spreads are driven more by the global financial markets than the country-specific variables. The following factors representing the overall climate of the global environment are employed in the analysis:

- US Stock Market Returns: The S\&P 500 composite index is employed in order to reflect the risk appetite as indicated by U.S. equities. In order to fully reflect the stock market developments, not only the excess returns but also the monthly returns (as calculated by the changes in S\&P 500 composite index) have been employed.

- US Treasury yields: As for the cds spreads 5 year maturity is selected as reference term, the S\&P 5-Year U.S. Treasury Note Excess Return Index is employed in order to address the fluctuations in the bond returns. In addition to this index, the yields of 5 year constant maturity treasury (CMT) rates computed by the Federal Reserve Board are also employed. CMT is based on the corresponding Treasury yield curve rate and is usually computed by averaging either the past week's or the past month's daily rates of the underlying constant maturity Treasury.

- Corporate Yields: The index of the spread of the US corporate with rating AAA minus that of US corporate with rating A as produced by Merrill Lynch is used. For the difference in the spreads of the US non-investment grade corporate with BBB and B ratings, the difference of the indexes for the both group of the corporate as produced by Thompson Reuters is used. Both of the variables are perceived as the measure of risk/return preferences of the investors.

- Equity Premium: The monthly price/earnings ratio for the S\&P 100 index is used as a measure of equity premium.

- Volatility Premium: Chicago Board Options Exchange Market Volatility Index, also named as VIX, measuring the market's expectation of stock market volatility over the next 30 day period is used as a proxy for volatility premium. Among the market-level variables, changes in VIX, a proxy for market-wide risk aversion or the so-called "fear factor", have more significant explanatory power than others.

- Term Premium: The index calculated by Barclays to represent the spread difference between the US Treasury bonds with 5 years and 1 year maturity is used as a measure of the term premium.

- Bond and Equity Flows: The Datastream provides the net flow of mutual funds to global bond and global equity markets and those amounts are used. 
- Emerging Market Index: As a measure of the risk appetite towards specifically to the emerging market countries EMBI index as calculated by JP Morgan is employed. The EMBI index track foreign-currency denominated government bond yields for a number of emerging market economies and it is commonly used as measures of country risk.

\section{V.III. Correlations of the Variables with the cds Spreads}

The variables are intentionally selected with regards to their anticipated relationship with the cds spreads which is thought to have affected on the sovereign risk. In this framework, the correlation between monthly changes in the value of each variable and cds spreads may be questioned when evaluating their effect on the cds spreads. A correlation matrix indicating the pairwise correlations of each variable with the cds spreads for each sovereign is given in Table V.

Table V

Correlation Between the Monthly Changes of the Variables and cds Spreads

\begin{tabular}{|c|c|c|c|c|c|c|c|}
\hline & Russia & Brazil & Turkey & Korea & Greece & Spain & General \\
\hline FX Rate & 0,3789 & 0,6526 & 0,7760 & 0,6057 & 0,3267 & 0,2071 & 0,5311 \\
\hline FX Reserves & $-0,0666$ & $-0,1573$ & 0,0191 & 0,0284 & 0,3127 & $-0,0052$ & $-0,0006$ \\
\hline External Debt & $-0,0711$ & 0,0234 & 0,0638 & 0,1662 & $-0,0299$ & 0,3504 & 0,0668 \\
\hline Equity Index & $-0,7405$ & $-0,6002$ & $-0,7644$ & $-0,635$ & $-0,357$ & $-0,2147$ & $-0,6018$ \\
\hline Balance of Payment as \% of GDP & $-0,0397$ & $-0,0264$ & $-0,0802$ & $-0,0272$ & $-0,0483$ & 0,0768 & $-0,0319$ \\
\hline S\&P 500 Index & $-0,6377$ & $-0,5894$ & $-0,6546$ & $-0,6157$ & $-0,4927$ & $-0,3581$ & $-0,5830$ \\
\hline US Corp. Spread Diff. AAA-A & $-0,4347$ & $-0,4988$ & $-0,4084$ & $-0,4883$ & $-0,0656$ & $-0,1177$ & $-0,3792$ \\
\hline US Corp. Spread Diff. BBB-B & 0,0162 & 0,01 & 0,0254 & $-0,0252$ & $-0,0538$ & $-0,1123$ & $-0,0119$ \\
\hline CMT-5 years & $-0,2487$ & $-0,2366$ & $-0,1822$ & $-0,1973$ & $-0,1591$ & $-0,0726$ & $-0,1956$ \\
\hline 5 years UST Excess Returns & $-0,0887$ & $-0,114$ & $-0,1586$ & 0,0404 & $-0,0508$ & 0,0212 & $-0,0673$ \\
\hline EMBI & 0,4802 & 0,4922 & 0,4883 & 0,4675 & 0,269 & 0,1244 & 0,4223 \\
\hline Equity Premium & $-0,0613$ & $-0,1393$ & $-0,0897$ & $-0,0575$ & $-0,2658$ & $-0,0721$ & $-0,1052$ \\
\hline Volatility Premium & 0,5233 & 0,2971 & 0,5363 & 0,5069 & 0,1748 & 0,2029 & 0,4075 \\
\hline Term Premium & $-0,1804$ & $-0,1285$ & $-0,0811$ & $-0,0027$ & $-0,1471$ & $-0,0008$ & $-0,0946$ \\
\hline Bond Flow & $-0,1225$ & $-0,0199$ & $-0,1433$ & $-0,1213$ & $-0,1315$ & $-0,1499$ & $-0,1102$ \\
\hline Equity Flow & 0,0521 & 0,084 & 0,0767 & 0,0128 & $-0,0784$ & $-0,0505$ & 0,03073 \\
\hline
\end{tabular}

Also, by using the country specific eigenvalues as weights, a comprehensive correlation was calculated in order to measure the correlation of each variable and those correlations are given in the rightmost column of Table V. Also, in order to better address the co-movement between the cds spreads and global financial variables before and after the financial crisis, the correlations of each variable with individual countries cds spreads is given in Table VI. 
Table VI

Correlation Between the Monthly Changes of the Variables and cds Spreads Before and After Crisis

\begin{tabular}{|c|c|c|c|c|c|c|c|c|c|c|c|c|}
\hline & \multicolumn{2}{|c|}{ Russia } & \multicolumn{2}{|c|}{ Brazil } & \multicolumn{2}{|c|}{ Turkey } & \multicolumn{2}{|c|}{ Korea } & \multicolumn{2}{|c|}{ Greece } & \multicolumn{2}{|c|}{ Spain } \\
\hline & $\begin{array}{c}\text { before } \\
\text { crisis }\end{array}$ & $\begin{array}{l}\text { after } \\
\text { crisis }\end{array}$ & $\begin{array}{c}\text { before } \\
\text { crisis }\end{array}$ & $\begin{array}{l}\text { after } \\
\text { crisis }\end{array}$ & $\begin{array}{c}\text { before } \\
\text { crisis }\end{array}$ & $\begin{array}{l}\text { after } \\
\text { crisis }\end{array}$ & $\begin{array}{c}\text { before } \\
\text { crisis }\end{array}$ & $\begin{array}{l}\text { after } \\
\text { crisis }\end{array}$ & $\begin{array}{c}\text { before } \\
\text { crisis }\end{array}$ & $\begin{array}{l}\text { after } \\
\text { crisis }\end{array}$ & $\begin{array}{c}\text { before } \\
\text { crisis }\end{array}$ & $\begin{array}{l}\text { after } \\
\text { crisis }\end{array}$ \\
\hline $\begin{array}{l}\text { S\&P 500 } \\
\text { Index }\end{array}$ & -0.5 & -0.69 & -0.58 & -0.59 & -0.65 & -0.67 & -0.54 & -0.71 & -0.47 & -0.49 & -0.3 & -0.64 \\
\hline $\begin{array}{l}\text { Corp, } \\
\text { Spread Diff, } \\
\text { AAA-A }\end{array}$ & -0.23 & -0.67 & 0.08 & -0.72 & -0.04 & -0.69 & -0.26 & -0.69 & 0.14 & -0.25 & 0.01 & -0.35 \\
\hline $\begin{array}{l}\text { Corp, } \\
\text { Spread Diff, } \\
\text { BBB-B }\end{array}$ & -0.19 & 0.43 & -0.2 & 0.44 & -0.14 & 0.47 & -0.17 & 0.43 & -0.16 & 0.16 & -0.16 & 0.22 \\
\hline $\begin{array}{l}\text { CMT-5 } \\
\text { years }\end{array}$ & -0.36 & -0.22 & -0.43 & -0.18 & -0.23 & -0.17 & -0.29 & -0.17 & -0.42 & -0.05 & -0.16 & -0.03 \\
\hline $\begin{array}{l}5 \text { years US } \\
\text { Treasury } \\
\text { Excess } \\
\text { Returns }\end{array}$ & 0.28 & -0.23 & 0.08 & -0.18 & 0.14 & -0.31 & 0.41 & -0.21 & 0.34 & -0.23 & 0.21 & -0.25 \\
\hline EMBI & 0.11 & -0.65 & 0.04 & -0.65 & -0.12 & -0.64 & -0.1 & -0.68 & -0.1 & -0.38 & 0.04 & -0.34 \\
\hline \begin{tabular}{|l|} 
Equity \\
Premium
\end{tabular} & 0.16 & -0.13 & 0.01 & -0.17 & 0.01 & -0.13 & 0 & -0.1 & -0.08 & -0.32 & -0.12 & -0.08 \\
\hline $\begin{array}{l}\text { Volatility } \\
\text { Premium }\end{array}$ & 0.68 & 0.47 & 0.56 & 0.23 & 0.67 & 0.49 & 0.5 & 0.55 & 0.25 & 0.15 & 0.15 & 0.38 \\
\hline $\begin{array}{l}\text { Term } \\
\text { Premium }\end{array}$ & 0.11 & -0.32 & 0.16 & -0.26 & 0.04 & -0.15 & 0.23 & -0.18 & 0.25 & -0.39 & 0.16 & -0.25 \\
\hline Bond Flow & 0.14 & -0.16 & 0.36 & -0.06 & 0.24 & -0.22 & 0.09 & -0.18 & 0.08 & -0.19 & -0.15 & -0.29 \\
\hline Equity Flow & -0.2 & 0.09 & -0.16 & 0.12 & -0.15 & 0.13 & -0.19 & 0.06 & -0.26 & -0.05 & -0.16 & -0.05 \\
\hline
\end{tabular}

Referring to the correlations given in Table V and Table VI, the following determinations can be made:

- Amongst the country-specific variables, the equity index has the highest negative correlation with the cds spreads. While the correlation is above $-0,60$ for the countries in the emerging country segment, it is lower for Spain and Greece, respectively $-0,215$ and $-0,357$. This strong negative correlation is in line with the finding of Coronado et al. (2012) but the lower correlation of Greece and Spain contradicts with their finding that correlations are more significant in the case of the countries with higher risk premiums (Italy, Greece, Spain, Italy and Portugal) than the others with lower cds spread levels.

- There exist considerable positive relationship between the monthly changes in FX rates and the cds spreads (on average $+0,53$ ). As devaluation of the domestic currency 
generally signals difficulty in the external economical positioning of a country, such a parallel increase in the cds spreads is understandable.

- Although FX reserves and foreign indebtedness of a country have been regarded as amongst the major default risk components, such relations are not confirmed with the data employed referring to Table V.

- Amongst the global financial market variables, the highest and negative correlation exists between the monthly changes in S\&P 500 index and cds spreads of the selected countries. This finding is in line with the findings of Longstaff et al. (2011). There is extensive evidence that shocks to the US financial markets are transmitted globally. It is thought that US security prices incorporate information about economic fundamentals or market liquidity that is relevant to a broad cross-section of countries. Referring to Table VI, the negative relationship widens after financial crisis for each of the country reflecting a further highlighting the risk concerns of the investors.

- The correlation of the monthly changes in cds spreads and EMBI index represents a considerable positive relationship (on average $+0,42$ ). The EMBI widens as risk aversion increases, so do cds spreads. Table VI shows that generally positive or slightly negative relationship between two variables before crisis turn to higher negative relationship after crisis. It is noteworthy to mention that while the correlation of EMBI spreads and cds spreads are very low for Greece and Spain, they show a negative relatively high relationship after crisis like other emerging market countries analyzed.

- Accepting US Treasury bonds as a safe heaven, the sovereign bonds and US investment grade corporate bonds compete for funds as alternatives of the investment decisions. In this regard, the negative and relatively high relationship between the changes in the spread difference of US corporate bonds with AAA and A ratings and the cds spreads of the selected countries, which is $-0,379$ on average is understandable. Referring to Table $\mathrm{V}$, for Greece and Spain, the correlation is $-0,06$ and $-0,11$ respectively, meaning that they differ from the emerging market countries. However, the correlation increases considerably for both countries after the crisis as stipulated in Table VI.

- Another US- financial market indicator is spread difference of the corporate with BBB and $\mathrm{B}$ ratings. Table $\mathrm{V}$ shows a negligible correlation between those spreads and cds spreads. However, Table VI shows a different picture; while before crisis there exist negative correlations for all the countries, after crisis the relations become positive and relatively high for all of the countries. This can be explained in such a way that as risk aversion increases in 
financial markets, the sovereign, as well as non-sovereign US risks are regarded as within the same "risky" assets group.

- The relationship between 5 years US Treasury excess returns and cds spreads is ambiguous referring to Table $\mathrm{V}$ as both has a correlation of $-0,06$. However, Table VI signals a relatively high negative relationship after crisis although the relationship has positive sign before. This can be interpreted again with risk aversion in the market after crisis when funds flow to US Treasury as safe heaven, spreads fall while cds spreads widened. The correlation between the cds spreads and CMT index which is another indicator of US Treasury yield is higher as compared to 5 years UST Excess Returns.

- Amongst the variables representing the premiums, the monthly changes in the volatility premium as represented by VIX index has highest positive relationship with cds spread. This finding is in parallel with the findings of Longstaff et al. (2011), Pan and Singleton (2008) and Remolona et al. (2008).

- Unlike the expectations, the correlation of the monthly changes in the both flows, equity and bond, are not that significant.

\section{V.IV Results of the Regression Analysis}

Putting together all the selected and analyzed variables with regards to their relationships with the monthly cds spread changes of the selected sovereigns, firstly the regression was performed with only the country specific data, the computed t statistics for each variable is given in Table VII.

\section{Table VII}

Regression Analysis Results of Country Specific Variables on cds Spreads of the Selected Sovereigns ${ }^{1}$

\begin{tabular}{|c|c|c|c|c|c|c|c|}
\hline & Russia & Brazil & Turkey & & Korea & Greece & Spain \\
\hline FX Rate & $-1,25 *$ & 5,6 & 1,68 & * & 9,15 & $-0,94^{*}$ & 5,6 \\
\hline Equity Index & $-11,22$ & $-1,12$ & $-13,74$ & & $-1,28$ & $-7,71$ & $-1,12$ \\
\hline FX Reserves & $-3,12$ & $-3,76$ & $-1,33$ & & $-3,64$ & $-3,14$ & $-3,76$ \\
\hline External Debt & 5,79 & 2,46 & 5,48 & & 4,31 & $-4,57$ & 2,46 \\
\hline Balance of Payment as \% of GDP & $-3,02$ & $-4,45$ & $-1,58$ & $*$ & $-1,92 *$ & $-2,9$ & $-4,45$ \\
\hline Adjusted $\mathrm{R}^{2}$ & 0,7674 & 0,7206 & 0,8121 & & 0,8809 & 0,4701 & 0,7206 \\
\hline
\end{tabular}

$\mathrm{t}$ statistics having significance at 95percent confidence level is denoted by *.

Specifically, Adjusted $\mathrm{R}^{2}$ for each country shows that the individual country economical situation has significant effects on cds spreads except Greece who experienced considerable turmoil in its economical and financial position. Although it is presumed that this 
deterioration has to be reflected in the cds spreads, the announcement of ISDA that the credit event occurred in the form of restructuring inevitably created imbalances such as illiquidity which in turn may make the cds spreads meaningless.

The relationship between US Dollar against domestic currency rate and cds spreads is rather ambiguous as out of 6 countries 2 of them have negative signed $t$ statistics. One of the recent studies for explaining and predicting sovereign credit risk with exchange rate volatility revealed the facts that the exchange rate volatility has an important role in the structural model of sovereign risk but the market does not fully price in the sovereign balance sheet information into CDS spreads (Duyvesteyn and Marten, 2012).

When evaluating the affect of the variables in determining the cds spreads individually, the negative local stock market return coefficient across all the countries attracts attention. This can be understood in such a way that when many things go well in an economy this is reflected in the stock index to raise and cds spreads to fall. ${ }^{3}$

The relationship between the FX reserves of a country and cds spreads is also negative across countries. From the foreign lenders perspective, the higher FX reserve means higher payment capacity without the need of further financing, more generally a decline in foreign currency reserves, and/or a rise in the foreign debt default will increase cds spreads. ${ }^{4}$

The relationship between external debt and cds spreads is also impressive in having positive signed $t$ statistics in all countries except Greece again. This positive relationship is logical and confirmed with many other research such as the one performed by Garcia and Rigobon (2005), who find that risk-based measures of debt sustainability are closely related to spreads in the case of Brazil.

Balance of Payment as a \% of GDP is included in the model as an independent variable because it is believed that this ratio not only gives the general foreign exchange related position of a country but also relates its external position with the economical capacity. From Table VII, it is seen that the relationship between this variable and cds spreads is negative across all the countries which is also logical as this ratio increases so the inflow from abroad in terms of trade relations as well as capital flows and the perceived riskiness will decrease as reflected in cds spreads.

\footnotetext{
${ }^{3}$ The relationship between stock markets and the real economic activity has been extensively debated in the macroeconomic and the finance literature. Since 70's, standard valuation models establish that the aggregate stock market is determined by macroeconomic fundamentals [Cochrane (1991), Fama (1981)]. Evidence from the relevant research suggest the existence of such a linkage between that financial markets and economic fundamentals across a variety of markets and time horizons.

${ }^{4}$ See IMF GFSR (April 2006), Box 3.6 for sovereign CCA and impact of changes in debt structure.
} 
Despite all of these inferences, it is noteworthy to mention that many of the internal variables does not have significance at a 95 percent confidence level.

Broadening the perspective in the analysis of the cds spreads of the selected countries by adding the global financial factors, new regressions were realized and the produced $t$ statistics are given on Table VIII. First of all, comparing Adjusted $\mathrm{R}^{2 \text {, }} \mathrm{s}$ of Table VII and VIII, the considerable increase in the predictive capacity of the model for each country does worth to mention. With the inclusion of the global financial variables not only the predictive capacity increased, but also $t$ statistics especially of the country-specific variables gained significance in 95 percent confidence level as can be seen from Table VIII.

Table VIII

Regression Analysis Results of Country Specific and Global Variables on cds Spreads of the Selected Sovereigns ${ }^{1}$

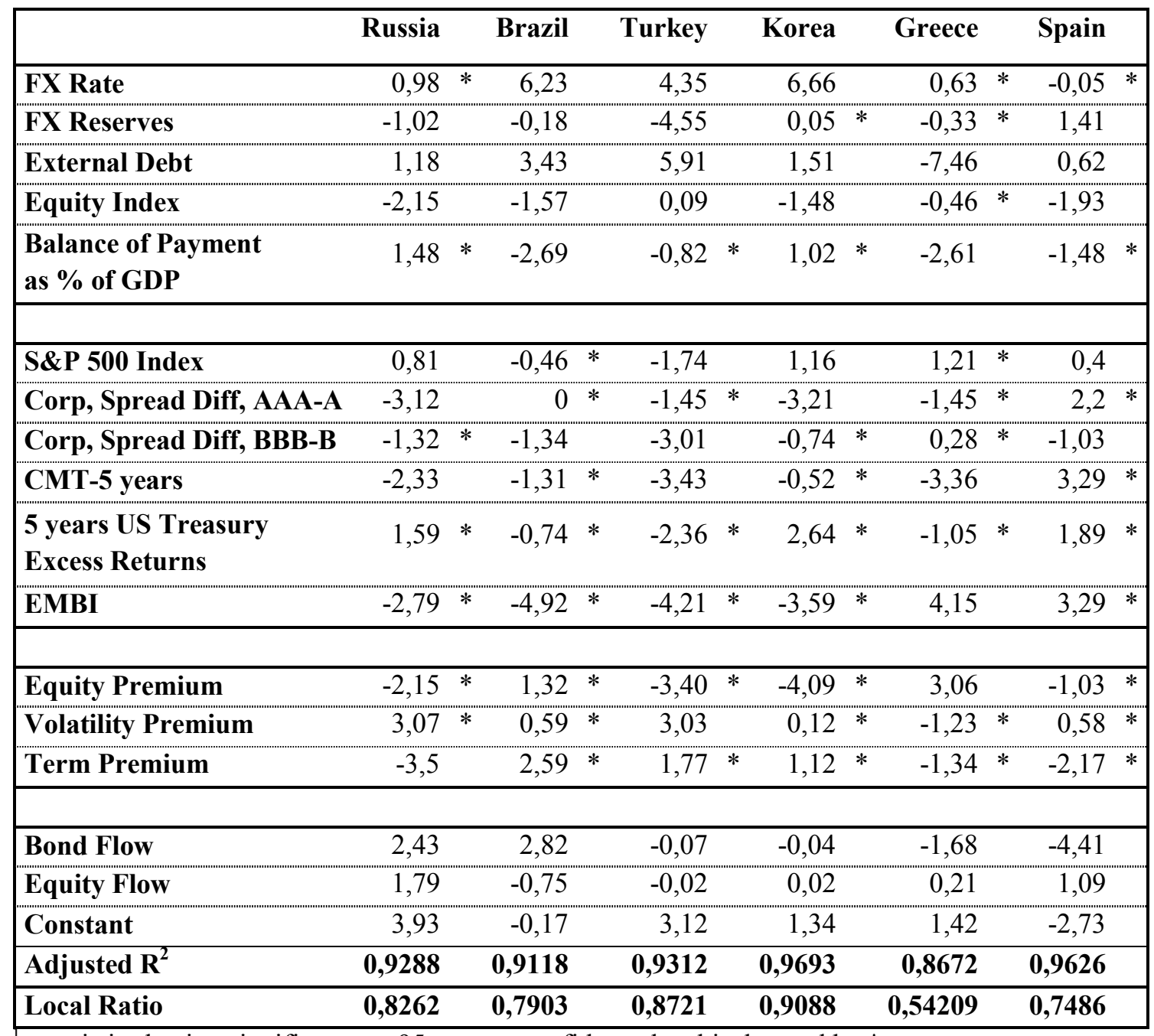

$\mathrm{t}$ statistics having significance at 95 percent confidence level is denoted by $*$.

In the last row of Table VIII, a new dimension was included named as Local ratio by Longstaff et al. (2011) which is calculated as Adjusted $\mathrm{R}^{2}$ of the model when only country- 
specific variables included divided by the Adjusted $\mathrm{R}^{2}$ when all variables are included. This ratio shows that except Greece, the local variables explain more than 75 percent of the cds spread level. The situation for Greece is exceptional as it has already experienced a quasidefault occasion. In fact, the low local factor ratio for Spain can be interpreted with the revised market pricing of cds transactions of Spain after the Greek experience. The other countries, all of which are in the emerging market segment, have local ratios near or above than $80 \%$ which means that their credit standing is highly dependent on the local macro economical environment.

Surprisingly, Balance of Payment as a \% of GDP ratio is the most significant local variable at 95 percent confidence level as $t$ statistics are significant for 4 countries out of 6 but the direction of the relationship reveals some ambiguity. For Russia and Korea, t statistics have positive sign unlike the other countries which can be explained by the fact that these two countries are net exporters.

The domestic equity index and cds spread are again negatively correlated except Turkey, but this variable is statically significant only for Greece. The external debt also keeps the direction of the relation as positive for all the countries except again Greece whose external debt in type of bonds have restructured to longer terms in the first quarter of 2012. The FX reserves variable is significant for Korea and Greece although the former indicates a positive and the latter a negative relationship.

From the Table VIII, it is seen that many of the global financial market variables have significant $t$ values for the countries involved. As parallel to the findings of Longstaff et al. (2011), the variable of 5 years US Treasury excess returns has significant $t$ values across all the countries. The direction of the relationship between cds spread is equally distributed among countries. A similar variable is Constant Maturity Treasury with 5 years maturity, 3 out of 6 countries it has significantly affected cds spreads.

The softening risk appetite generally results with a shift of funds from US Treasury to equity and relatively high risk bonds and the first address is to less risky shares as covered by S\&P 500 index, consequently increasing S\&P 500 index generally signals improved risk appetite which is expected to smoothen the cds spreads as well, so a negative relationship is expected but the results of the analysis does not support this view. The direction of the relationship is negative for Brazil and Turkey and positive for the others. The relationship between the 
monthly changes in S\&P 500 index and the cds spreads of the selected sovereigns has significance for 2 countries out of 6 .

In the market place, the return difference between the US corporate with AAA and A ratings decreases when the risk appetite smoothens, the same is true for also US corporate BBB and $\mathrm{B}$ difference as the investors will not differentiate the riskiness of the categories so a negative relationship is expected. The expectations are confirmed with the findings as can be seen from Table VIII as both of the variables have generally negative signs and it can also be said that this variable is also significant at 95 percent confidence level.

The other group of global variables are premiums of equity, volatility and terms measuring the relation of the cds spreads with price earnings ratio of S\&P 100 index, VIX and the index issued by Barclays indicating the spread difference between 5 and 1 year bonds respectively. From Table VIII, it is clearly seen that all the premiums are statistically significant in determining cds spreads at 95 percent confidence level.

The last interesting finding from Table VIII is that funds flow from US to invest to whether bonds or equity does not affect the cds spreads considerably although funds flow is expected to rise in good times when also cds spreads narrow.

\section{CONCLUSION}

The protection provided by a cds transaction has gained importance especially after the quasidefault situation of Greece. The market participants have begun to question not only the dissolution procedure of the cds transactions after the realization of a credit event but also the protection they provided and whether the cds spreads truly reflect the credit risk of the sovereign. The cds spreads should reflect the developments in the country-specific macroeconomic fundamentals affecting the default probability of a sovereign in order provide hedging capability. However cds is a tradable instrument, the spreads are determined in the market place so inevitably are affected by the market climate. Many researchers have focused on the local and global factors affecting the cds spreads and this study also aimed to figure out the cds spreads of six countries, namely Brazil, Russia, South Korea, Turkey, Greece and Spain. The first four countries are amongst the emerging market segment and intentionally selected representing different geographical locations, as well as trade positions and Greece and Spain were selected in order to capture the possible dynamics in the cds spreads in case of quasi-default and default rumors which are the cases for them respectively. 
Whatever the source of commonality, it is a fact that the cds spreads of the sovereigns do move together as indicated by high correlation among the cds spreads of the selected countries for the period between May 2005 till May 2012 covering the crisis times of 20082009 as well as Euro-sovereign crisis. When evaluating the pair-wise correlations of monthly changes of the cds spreads the decomposition of Greece and Spain from other countries is seen easily. This decomposition may be attributable to the troublesome conditions they face but also to their origination to Euro area of economical cooperation and the developed nature of their economies. Not surprisingly, the emerging market countries have high correlations amongst themselves as the internal and external factors affecting their credit riskiness are similar. The monthly cds spreads movements are not only correlated highly but also a limited number of common factors have affect all of the sovereigns as 62 percent of the variation is explained by the first common factor and the first three component captures nearly 90 percent of the correlation.

The relation of the cds spreads with some index such as S\&P 500 index and VIX have been analyzed by many of the researchers and the result is parallel to earlier findings such that the principal source of variation across the sovereign cds spreads of the selected countries comes from US stock market return and volatility as defined by those indexes.

The correlation of the monthly changes in each variable with that of the cds spreads indicated a very significant negative relationship between domestic equity index (Greece and Spain decomposed) and a relatively significant positive relationship with FX rates against US Dollar. The relation with FX reserves and foreign indebtedness are not confirmed although these variables may be considered to be amongst the determinants of the credit riskiness of a country. The relation was even loose for the variable which is specified as the balance of payment as a percentage of GDP.

Amongst the global financial variables, the most influential are US equity indices as represented by S\&P 500 index with a high degree of negative correlation and EMBI with a high degree of positive correlation. Another impressive finding is that the differences between the spreads of US corporate with AAA and A ratings and $\mathrm{BBB}$ and $\mathrm{B}$ ratings have negative and relatively high correlations. Notably, the correlation between the monthly changes in cds spreads and VIX index is also positive and high. 
The financial market related variables and their relationships with cds spreads reveal the fact that the risk appetite in the global financial market affects the credit risk perception and consequently the cds spreads regardless of the employed indicator of the risk appetite. But, the portfolio flows do not have significant relation with cds spreads, may be steaming from their probable lagging occurrences.

In fact, the regression analysis produced supportive results to the above mentioned determinations. Specifically, it is revealed that individual country economical situation has significant effects on cds spreads except Greece who experienced considerable turmoil in its economical and financial position. More specifically it is seen that except Greece, the local variables explains more than 75 percent of the cds spread level and this ratio increases to more than $80 \%$ when four emerging market countries are referred.

Adding global financial variables into the system not only increased the predictive capability of the model but also increased the significance of the contributions of the local variables more significant so making the overall model more predictive. 


\section{REFERENCES}

Ang, A., \& Longstaff, F.A. 2011. Systemic Sovereign Credit Risk: Lessons from the U,S, and Europe. NBER Working Paper No.16982, National Bureau of Economic Research, Cambridge, MA.

Augustin, P., \& Tedongap, R. 2011. Common Factors and Commonality in Sovereign CDS Spreads: A consumption-based explanation. Banco de España - Bank of Canada Workshop on Advances in Fixed Income Modeling, Madrid.

Baek, I., Bandopadhyaya, A, \& Chan, D. 2005. Determinants of market-assessed sovereign risk: Economic fundamentals or market risk. Journal of International Money \& Finance, 24: 533-548.

Cantor, R., \& Packer, F. 1996. Determinants and impact of sovereign credit ratings. Economic Policy Review, 2(2): 37-58.

Catão, L, \& Sutton, B. 2002. Sovereign Defaults the Role of Volatility. International Monetary Fund Working Paper NO.149:16-18.

Cho, D. 2010. Responses of the Korean Economy to the Global Crisis:Another Currency Crisis? Paper presented at 2010 EWC/KDI Conference on Global Economic Crisis: Impacts, Transmission, and Recovery in Honolulu, Hawaii.

Cochrane, J. 1991. A critique of the application of unit root tests. Journal of Economic Dynamics and Control, 15(2): 275-284.

Coronado M., Corzo, M.T., \& Lazcano, L. 2012. A Case for Europe: The Relationship between Sovereign CDs and Stock Indexes. Frontiers in Finance and Economics, 9(2), 32-63.

Duyvesteyn, Johan G. and Martens, Martin, Forecasting Sovereign Default risk with Merton's Model (October 15, 2012) <http://dx.doi.org/10.2139/ssrn.1839470>

Fama, E.F. 1981. Stock Returns, Real Activity and Money. The American Economic Review, 71(4):545-565.

Fontana, A., \& Scheicher, M. 2010. An analysis of euro area sovereign CDS. European Central Bank Working Paper Series, no.1271. 
Garcia, M, \& Rigobon, R. 2005. A Risk Management Approach to Emerging Market's Sovereign Debt Sustainability with an Application to Brazilian Data. In F. Giavazzi, I. Goldfajn, \& S.Herrera (Eds,), Inflation Targeting, Debt and the Brazilian experience 1999 to 2003, 53-75, MIT Press.

Garcia-Herrero, A., \& Ortiz A. 2007. The role of global risk aversion in explaining Latin American sovereign spreads. Economia, 7(1), 125-155.

Georgievska, A, Georgievska, L., Stojanovic, A., \& Todorovic, N. 2008. Sovereign rescheduling probabilities in emerging markets: a comparison with credit rating agencies' ratings. Journal of Applied Statistics, 35: 1031-1051.

Hilscher, J., \& Nosbusch, Y. 2010. Determinants of Sovereign Risk: Macroeconomic Fundamentals and the Pricing of Sovereign Debt. Review of Finance, 14: 235-262.

Kamin, S., \& von Kleist, K. 1999. The Evolution and Determinants of Emerging Market Credit Spreads in the 1990s. Working paper No, 68, Bank for International Settlements.

Longstaff, F.A., Lasse, J.P., Pedersen, H., \& Singleton, K.J. 2011. How Sovereign Is Sovereign Credit Risk? American Economic Journal, 3: 75-103.

Mauro, P., Sussman, N., \& Yafeh, Y. 2002. Emerging market spreads: then versus now. Quarterly Journal of Economics, May :695-703,

McGuire P., \& Schrijvers, M. A.2003. Common factors in emerging market spreads. BIS Quarterly Review, 32: 65-78

Mellios, C., \& Paget-Blanc E. 2006. The impact of macro-economic variables on the sovereign CDS spreads of the Eurozone countries: Examining the determinants of credit default swaps. Journal of Finance, 12 (4): 363-382.

Pan, J. \& Singleton, K. J. 2008. Default and recovery implicit in the term structure of sovereign cds spreads. The Journal of Finance, 63(5): 2345-2384.

Reinhart, C, \& Rogoff, K. 2008. This time is different: Eight Centuries of Financial Folly. New Jersey: Princeton University Press. 
Remolona, E., Scatigna, M., \& Wu, E. 2008. The dynamic pricing of sovereign risk in emerging markets: Fundamentals and risk aversion. Journal of Fixed Income, 17(4): 57-71.

Weigel, D., \& Gemmill, G. 2006. What Drives Credit Risk in Emerging Markets? The Roles of Country Fundamentals and Market Co-Movements. Journal of International Money and Finance, 25: 476-502.

Westphalen, M. 2001. The determinants of sovereign bond credit spreads changes. Working paper, University of Lausanne. 